\title{
SOCIAL MEDIA MARKETING: PROSPECTS AND OPPORTUNITIES FOR SMALL AND MEDIUM ENTERPRISES
}

\section{Muhammad Ovais Jummani ${ }^{1}$ and Sadia Shaikh ${ }^{2}$}

\begin{abstract}
This paper aims to explore prospects and opportunities of the use of Social Media Marketing tools by Small \& Medium Enterprises (SMEs) in Pakistan, to develop and promote their business. The research data findings postulate the fact that the SMEs constitute over 90 percent of 3.2 million business enterprises listed under Economic Census of Pakistan (2005,) generate 25 percent of manufacturing export earnings and contribute 30 percent to the annual GDP in the country. Despite this fact, the SMEs are considered to be less formally organized sector of the economy relative to large enterprises, have limited access to financial resources and are limited to their scale of production. Social Media Marketing, on the other hand, operates on a less complex organizational structure, requires lower financial investments and even makes an organization appear to be larger than its actual size. These analogous attributes establish a correlation between SMEs and Social Media Marketing. This paper intends to identify the various possibilities which can contribute to the growth and development of the SME sector in Pakistan. The study examines the data evidence and empirically tests the correlation between SME business progress \& social media as a mode of business promotion. Consequently, this research paper focuses on how small businesses can use the Social Media not only for advertising and marketing of their products and services but also building the business overall, employing transactional mechanisms, sharing information with customers and receiving their feedback and recommendations on a regular basis.
\end{abstract}

Keywords: Small \& Medium Sized Enterprises; Social Media Marketing; Transactional Marketing Mechanisms.

\section{INTRODUCTION}

The basic ideologies of the global socio-economic development in the 21 st century have been abruptly transformed due to massive technological advancements and disruptions. The recent

\footnotetext{
${ }^{1}$ Mobilink, Pakistan

${ }^{2}$ Greenwich University, Karachi, Pakistan
} 
past decades have witnessed a substantial rise in global attention and interest in entrepreneurship subject, particularly in small and medium enterprises. This concentration can be synchronized in the realm of evolving global economic concerns, escalating poverty incidences, relentless income inequalities, altering social structures, and widening socioeconomic gaps. The increased interest in the small and medium enterprises upholds a valid approach, considering the comprehensive research evidence that asserts the small and medium firms to be a critical driving force of economic progress (Kharub \& Sharma, 2020). SMEs significantly contribute to the Gross Domestic Product (GDP), increase productivity, enhance tax revenues, create tremendous employment opportunities, and aid the balance of trade through exports thus, enormously add to the overall economic output (Gherghina, Botezatu, Hosszu, \& Simionescu, 2020; Chong et al. 2019; Tripathi, 2019).

The SMEs role to stimulate the economic cycle is particularly predominant in developing economies, where the proportion of the human capital workforce to the available employment opportunities is relatively small. Similarly, the contribution of SMEs in Pakistan is consistent with the other developing economies. The SMEs constitute over ninety percent (90\%) of the 3.2 million businesses enterprises listed under the Economic Census of Pakistan, generate twenty-five percent $(25 \%)$ of manufacturing export earnings, contribute thirty-five percent $(35 \%)$ to the manufacturing value addition and nearly thirty percent (30\%) to the annual GDP. Besides, SMEs in Pakistan employ nearly eighty percent $(80 \%)$ of the non-agricultural labor force and are a source of livelihood to millions of people.

What distinguishes SMEs is that unlike large enterprises that are considered an integral part of the formal economy, most small and medium enterprises fall within the "less formally organized sector" according to SMEDA (2005). They have limited access to financial resources and are limited in their scale of operation. This inherent feature makes SMEs dependent on government infrastructural support that may relate, inter alia, to preferential treatment in the allocation of credit, institutional support for technical up-gradation and the development of skilled human resources.

Currently, the new wave of social media trend has taken the majority of the world populace into its influence. Consumers comprising a diverse range of demographic cohort including boomers to generation $\mathrm{Z}$ and the new generation Alpha, all are seen accustomed to social media handling. Similarly, the emerging micro and small businesses run by the people belonging to this cluster are observed to be more inclined to find new promotional channels for their businesses, through the social media platform. This study is thus intended to explore prospects 
and opportunities of the use of social media tools by SMEs to develop and promote their businesses. Although it is a thriving trend, social media can benefit SMEs as much as, if not more than large size enterprises. The social media operates on a less complex organizational structure, requires lower financial investments, and even makes an organization appear to be larger than its actual size, which makes it favorable to the SMEs ${ }^{11}$.

Consequently, this paper will focus on how small businesses can utilize the social media tools not only for advertising and marketing of their products and services but also building the business overall, by means of transactional mechanisms, sharing information with customers and receiving their feedback and recommendations on a regular basis. In developing economies due to financial and other institutional barriers, SMEs face genuine problems in leveraging customers and cannot afford the colossal advertising budgets that the more established, more affluent "big business" can, either at the national level or globally.

\section{LITERATURE REVIEW \\ Electronic Commerce (e-commerce)}

Electronic commerce or e-commerce has been a subject of considerable interest for business organizations and many authors and academicians since the 1990s. One of the first definitions is attributed to Zwass (1996), which described e-commerce as "sharing of business information, maintaining business relationships and conducting business transactions by means of telecommunication networks". Later researchers opined that the definition fitted perfectly well to the present time simply by replacing "telecommunication networks" with the Internet. Poon et al (1997) conducted twenty-three case studies of small businesses in Australia to identify the roles played by the internet in small businesses and identified the drivers for internet use and the perceived benefits for the firm using the medium. The detailed study classified the firms based on years of internet use, and key reasons for using the internet, to derive the patterns of behaviour among participating businesses, concerning investigation on i) the role of the internet as a medium of communication; ii) management's enthusiasm for internet use in the business; iii) perceived benefits from internet use; iv) differences in internet usage among industries; $v$ ) the extent of integration between the internet and internal management systems, and vi) the need to be an entrepreneur in internet applications. In this regard, Pool et al (2006), concluded that many firms were still struggling to determine whether e-commerce could bring advantages to their business but concluded that the most critical 
factors affecting internet use in the businesses were management commitment and the perceived benefits.

As business activities on the internet gained much momentum, an increasing number of research efforts were undertaken in the more developed markets to evaluate its impact using business models. However, relatively few of these focus on how the Internet has affected small businesses. Barker (1994: 81), is among the first researchers who conducted research on the importance of the internet for small businesses. He concluded that searching for customer information and obtaining specific information for marketing purposes were the most important benefits the internet offered to small businesses. He projected that small businesses in the well-established markets, who are functioning under internet driven knowledge and information-based industries, niche markets and new business types that fit well with the medium are the main groups that will be the first to benefit from the Internet.

In the broadest sense, e-commerce refers to all online transactions taking advantage of the internet growth to allow organizations to conduct business with improved efficiencies and productivity (Sharma \& Gupta, 2003). Additionally, e-commerce can enhance an organization's image, enable access to new customers, and generate new business opportunities (Chan, 2003). Even with the excessive optimism of e-commerce in 1990s and collapsed dotcom enterprises in 2001, e-commerce continued to grow.

In the UK at the turn of the century, Daniel, and Wilson (2002) found that firms adopting ecommerce did not gain as many benefits as they expected. Unfortunately, the benefits SMEs expected from the implementation of e-commerce did not match the drivers that actually persuaded them to adopt e-commerce (Daniel \& Wilson, 2002). In their extended study, Daniel, and Wilson (2004), also found that the greatest benefits to firms are limited to internal knowledge sharing and communication between employees within the firm.

Today e-commerce is receiving much greater attention because of the widespread availability of the internet that is playing a key role in the process. It is differentiated into three types: business-to-business (B2B), business-to-customer (B2C), and customer-to-customer (C2C) ecommerce. Even the global retail ecommerce sales are expected to stretch to $\$ 27$ trillion by end 2020. The internet had also graduated from being a research and connectivity network, to a veritable tool of business. Businesses large and small have either seized the opportunity and use it or are exploring how best they can use it to become more productive, more competitive and more profitable. Evidence suggests that the pace of development in e-commerce in developing countries such as BRIC is much faster than in the more mature markets. 
The world without internet is simply unimaginable today. It has emerged as a new basic necessity of the humans to survive, as an extension to the Maslow's hierarchy of needs. In April 2020, almost 4.57 billion people were active internet users, encompassing about 59 percent of the global population. According to the Global Digital Overview (2020), approximately 3.81 billion people which make about 84 percent of the global internet users, actively use social media each month. During the recent upheaval of COVID-19, when the world's larger population has isolated themselves in homes, the e-commerce industry has witnessed a massive boom and is expected to proceed in a similar or faster pace in the upcoming years. The pandemic has undoubtedly manifested the transformation of the digital world and e-commerce, globally. It can thus be said that if internet was a national economy, it would rank among the world's top five economies behind US, China, Japan, and India and ahead of Germany. As reported, the internet is contributing up to 8 percent of GDP in some economies, creating wealth and also fueling jobs. Comparably, the social networking sites reach about 80 percent of users in developed and developing economies alike.

\section{Social Media}

Social media operates on "web-based" and "mobile-based" technologies to effectively transform communication into interactive dialogue between and among organizations, communities, and individuals. For the end-user, this takes on many different formats - the more prevalent among them being blogs, picture-sharing, vlogs, wall-postings, email, instant messaging, music-sharing, crowd sourcing and voice over IP, to name a few. Delerue, Kaplan and Haenlein (2012), classified social media into six broad categories: i) collaborative projects (e.g., Wikipedia), ii) blogs and micro blogs (e.g. twitter, LinkedIn, WordPress, Tumblr, MySpace), iii) content communities (e.g. YouTube, Instagram, Reddit, Pinterest), iv) social networking sites (e.g. Facebook, QQ, Messenger, Snapchat, Viber, Bebo), v) virtual game worlds (e.g. World of Warcraft), and vi) virtual social worlds (e.g. WeChat, WhatsApp, Telegram, Second Life).

Many of these social media services can be integrated via social network aggregation platforms. Contrary to popular belief, social media did not start with the likes of Facebook and Twitter. According to experts, social media started almost one and a half decade ago in the mid-1990s, with communication through emails and SMS. Large retailers in the US like Walmart used emails for order placement and inventory management, and banks used it to cut cost by eliminating clerical jobs and substituting email for expensive overnight deliveries 
of mail. Hence, it is not entirely new, even though it has proliferated and gained popularity in more recent times.

The number of social media users too has been growing radically in the new millennium and taken multiple shapes and forms. Constantinides and Fountain (2008) classify social media on the basis of their application types: Blogs and podcasts, social networks, communities, content aggregators, virtual worlds.Google analytics data confirm that there are 4.39 billion internet users worldwide (in 2019). Facebook database claims the existence of 2.6 billion monthly active Facebook users worldwide (March 2020) and in Pakistan the number is 37.07 million users. The recent surge in the number of users on Facebook and other social media sites has created the impression that social media is a contemporary phenomenon, which is completely wrong.

An overwhelming response to social networks and online communities like Facebook is evidence of its effectiveness as a tool for marketing focused either on a localized audience or on a global scale. This has attracted several major Telecoms like Zong and Mobilink, as well as Education Consultants, Forex companies, recruitment agencies and private brand owners to either create a full complement of material using corporate websites or displaying their banners on other as part of a large-scale national campaign.

The initial cost of banner advertising on sites like Yahoo or Hotmail was exorbitant. Yahoo through its agent in the Middle East (www.dotcomacarabbia.com) quoted a price of "US $\$ 6,000$ for displaying your banner 300,000 times in a month" with an incentive that volume discounts would apply. Later the cost came down to US\$1500 per advertisement banner. Once Facebook arrived offering advertisement banners for US\$5, advertising rates on the internet came crashing down. This does explain in a large part the boom-time that followed and social media sites like Facebook, Twitter, Linked-In, and Skype brought in a new era of change in communication. Facebook advertisement charges now work on the basis of CPC (Cost per click) or number of impressions. The rate varies as well based on the number of "takers" as bidding now takes place under the newly inducted system of auctions.

\section{Social Commerce}

A term that stated to appear in the literature in 2005 was Social Commerce, for some experts a coming together of business and the social media. However, more than just a buzzword for the combination of social media and ecommerce, Social Commerce represents an emerging 
phenomenon driven by the proliferation of Web 2.0 (Wang, 2009). Through various formats including chat rooms, locator applications (geo-tagging), blogs, podcasts, tagging, social networks, ranking, recommendation systems, etc. social commerce enables consumers to share information, experiences and opinions about what, where and from whom to buy (Jascanu, Jascanu \& Nicolau, 2007). The term "Social Commerce", as it is said, was introduced by Yahoo! in 2005, with the earliest academic article using it in 2007 (Jascanu, Jascanu \& Nicolau, 2007).

\section{Internet and its Impact on Economic Development}

According to Cheng and Shiu (2019), businesses particularly small and medium size enterprises (SMEs), regarded as the growth engine of most economies, are moving online in increasing numbers, however, due to less knowledge and awareness, comparably few SMEs use social media tools (Agrawal, \& Saxena, 2019; Bradshaw, Dodds, Crumbley, Sutherland, \& Shaw, 2019).

The BCG's e-intensity index, measures each country's level internet maturity through enablement (the amount of internet infrastructure that it has in place), expenditure (the amount of money spent on online advertising) and engagement (the degree to which businesses, government and consumers are involved with the internet) and is a sound indicator of gauging the potential of the medium. South Korea, Denmark, Sweden, Iceland, and the U.K top the list with the largest contribution to GDP. India and China stand out for their enormous internetbased export - China in goods and India in services - which propel their internet economy ranking towards the top of the chart.

According to the Economist Intelligence Unit of the Organization for Economic Cooperation and Development (OECD); country statistical agencies: India has internet economy of 5 percent of GDP in 2019 and will grow to 7.5 percent in 2020. Thus, it clearly justifies the potential of expanding business via internet in the region of South Asia.

David Dean et al. (2012), found that ROPO (Research online, purchase offline) spending is higher than online retail in almost every country that was studied including India, China, South Africa, Turkey, and South Korea. This indicates that even in developing countries people do not merely go online for research but also for making purchases. David Dean et al (2012), also identified five value levers to explain the internet advantage of "High-Web" SMEs, including, geographic expansion, enhanced marketing, improved customer interaction, leveraging the 
cloud, and easier and quicker staff recruitment. The study analyzed three year sales trends in "High Web SMEs" and "Low or No-Web SMEs" in several countries to conclude that there was enough proof that SMEs that made more extensive use of web grew at a faster rate compared to those that did not. Results showed, for instance, that High Web SMEs in China were growing nearly 15 percent faster than Low or No-Web SMEs. In Brazil the growth was 8 percent faster, in India 5 percent, in Turkey 22 percent, in Germany 14 percent, in USA 15 percent, in France 3 percent and in South Korea 11 percent.

According to research conducted by the Boston Consulting Group (BCG), report published in March 2012, titled "The Connected World - The \$4.2 Trillion Opportunity" - The internet opportunity in G-20", amongst all G-20 countries the world's focus was on India. Though India has a huge population of more than 1.2 billion people, literacy rate in the country is better than Pakistan, the economy more vibrant and the use of internet significantly more prevalent. Correspondingly, the KPMG (2017), report asserts that the e-economy of India is in an unparalleled growth trajectory, expected to surpass USD $\$ 80$ billion in 2020. Even the online users in India are expected to outperform USA and its economy will become second largest internet users base in 2020. Similarly, the comparison of Indian SMEs (High-Web) with those of SMEs in developed country show a similar pattern of adoption of internet for online advertisement and performing transactions using e-commerce, whereas the Low Web SMEs demonstrate a dissimilar exhibit. Thus, a mega market of SMEs in South Asia subsists which can immensely evolve through adoption of social media tools.

As discussed above the proportion of internet users is increasing significantly around the world, and a similar trend is being witnessed in Pakistan. According to the International Telecommunications Union (ITU) there were just $1.3 \%$ of internet users in the country in the year 2001 which upsurged to $36.18 \%$ which makes around 76 million citizens of the total population having access to the internet in 2019. Internet growth rate in Pakistan has been among the fastest in the region.

A number of e-business start-ups have consequently emerged selling their wares online through their websites leveraging on Cash on Delivery (COD) and online payments. Many business use integrated portals with the company's inventory system and show updated stock levels as well as approximate details of arrivals of fresh stock. Similarly, companies use email marketing, social community networks, and Search Engine Marketing (SEM) extensively for creating 
brand awareness as well as for sales transactions. However, SEM provides limited support for building brand image, increasing repeat purchase or disseminating information about products because of its constraints in content quantity and linear format.

Comparably, many small businesses, which lack exorbitant investment amounts and physical office spaces use social media platform and have proven by successfully running businesses without massive investment or start-up cost.

In this era of continuous advancements in cellular technology future trends indicate rapid growth in the use of $4 \mathrm{G}$ technology in urban as well as remote rural areas that would adequately support business advertising.

Empirical studies suggest that social media and internet can be extremely useful for SMEs intending to extend its reach beyond metros and even beyond borders. Studies indicate that some changes in attitudes as well as organization structure and processes would be necessary to make e-commerce on the social network more successful. Studies also affirm that using the internet can improve sales of items which are not that costly, although buyers of big-ticket items use the net to gather information before going over physically to a store to complete the purchase transaction. On the other hand, there are examples of developing countries such as India, Turkey, and South Africa where internet usage for business is at an elevated level and contributes substantially towards the countries' GDP.

\section{RESEARCH HYPOTHESES}

With the review of previous literature and keeping the study objectives in mind, following hypothesis were devised for this study:

$\mathrm{H}_{1}$ : SMEs are unfamiliar with and inactive in using internet for business.

$\mathrm{H}_{2}$ : SMEs in Pakistan lack awareness about promoting businesses through the social media.

$\mathrm{H}_{3}$ : There is a positive relationship between opportunities in SMEs business and internet usage for business.

$\mathrm{H}_{4}$ : Use of social media is only beneficial for a few types of SMEs.

$\mathrm{H}_{5}$ : SMEs use internet mainly to enhance company image.

$\mathrm{H}_{6}$ : SMEs prefer SMS marketing over internet or social media marketing. 


\section{RESEARCH METHODOLOGY}

The study is based on quantitative research analysis. The study survey comprised of closeended questions developed on Google docs. The questions were formulated on the 5-point Likert scale format. A sample size of 124 respondents was selected through stratified random sampling with the proviso that they were bona fide owners of SME's and had a yearly income of more than PKR 500,000/. To collect the data, questionnaires were distributed to SME owners through Emails and personal visits. The collected data was analyzed using SPSS software in order to conduct correlation, regression and other statistical tests and make inferences from the obtained secondary data.

\section{Sample Characteristics}

\section{DATA ANALYSIS}

The survey consisted of interviews of 124 SME owners conducted on site. More than half (55percent) of the SMEs covered had 20 or fewer employees. The next group in size (27percent) consisted of firms employing between 21- 70 persons.

In terms of turnover 31 percent of the sample had less than Rs 50million turnover in the preceding year (2011) whereas 22 percent achieved between Rs. 51-100 million. A third of the sample fell within the Rs. 201-350 million in terms of turnover creating a better balance in the sample.

\section{Table 1}

No. of Employees * Business Turnover Crosstabulation

\begin{tabular}{|c|c|c|c|c|c|c|c|c|c|}
\hline & & \multicolumn{7}{|c|}{ Business Turnover } & \multirow[b]{2}{*}{ Total } \\
\hline & & $\begin{array}{l}\text { less than } \\
50 \mathrm{~m}\end{array}$ & 51 to $100 \mathrm{~m}$ & 101 to $150 \mathrm{~m}$ & 151 to $200 \mathrm{~m}$ & 201 to $250 \mathrm{~m}$ & 251 to $300 \mathrm{~m}$ & $301 \mathrm{~m}$ or more & \\
\hline No. of & 20 or less & 38 & 20 & 0 & 2 & 4 & 4 & 0 & 68 \\
\hline \multirow[t]{5}{*}{ Employees } & 21 to 70 & 0 & 0 & 4 & 9 & 10 & 10 & 0 & 33 \\
\hline & 71 to 120 & 0 & 7 & 2 & 0 & 0 & 0 & 0 & 9 \\
\hline & $121-170$ & 0 & 0 & 0 & 0 & 0 & 0 & 7 & 7 \\
\hline & 171 to 220 & 0 & 0 & 0 & 0 & 0 & 0 & 3 & 3 \\
\hline & 221 or more & 0 & 0 & 0 & 0 & 0 & 0 & 4 & 4 \\
\hline Total & & 38 & 27 & 6 & 11 & 14 & 14 & 14 & 124 \\
\hline
\end{tabular}

Cross-tabulation of two characteristics viz. number of employees and turnover revealed that nearly a quarter (almost 25 percent) of the sample had a turnover of less than Rs 50 million and employed 20 persons. 
Figure 3

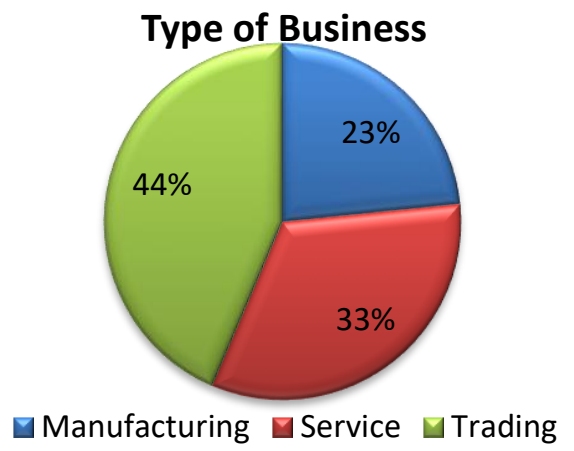

Figure 3 identifies the sample by type of business indicating that Traders ( 44 percent) rightfully occupied a majority share followed by SMEs in the Service industry (33 percent) leaving less than a quarter share (23 percent) for small manufacturers.

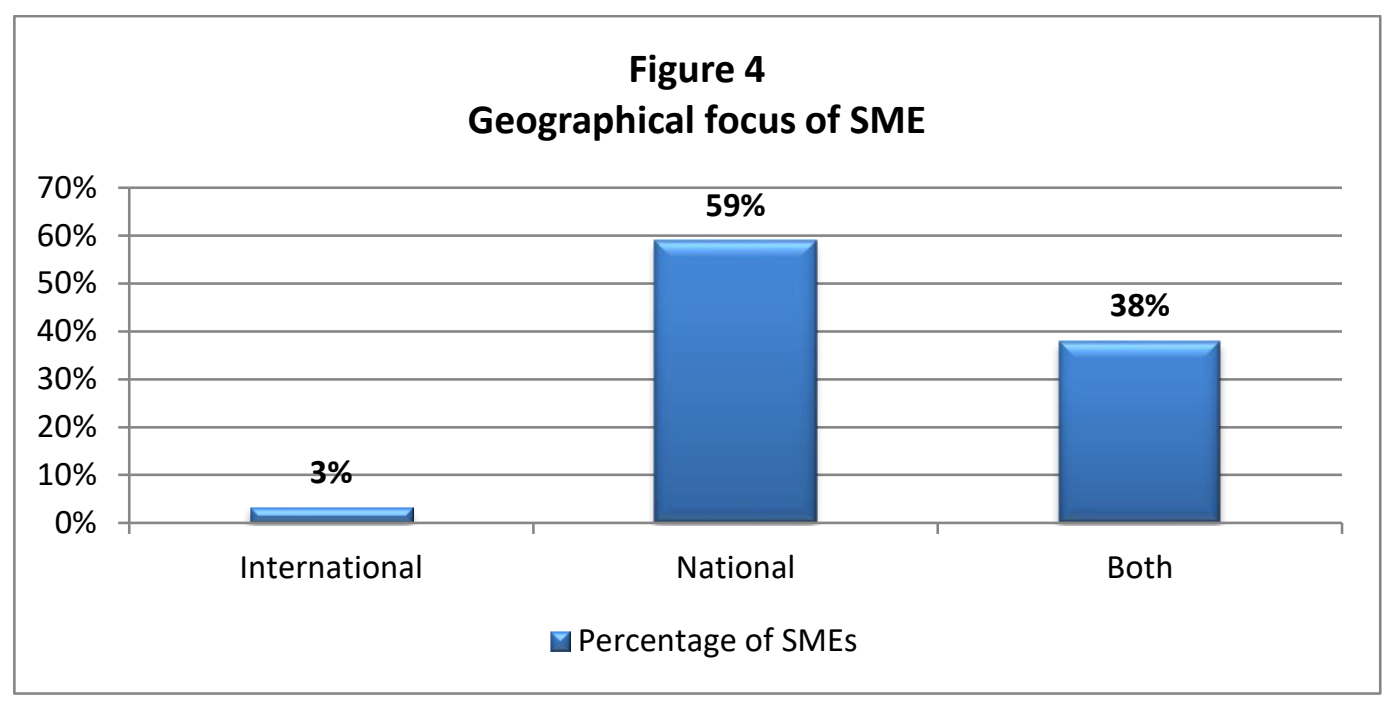

In terms of geographical focus, more than half of the SMEs (59 percent) concentrated on the national/local market only for business whereas 38 percent were involved in a combination of national and international business. Only 3 percent focused specifically on the international market. The main reason cited for the limited focus on the international market was the tough competition from regional players such as Sri Lanka and Bangladesh, as well as from other developing countries like India, China, and South Africa.

\section{Testing the Hypotheses}

\section{Hypothesis \# 1}

$\mathrm{H}_{0}$ (1): SMEs are unfamiliar with and inactive in using internet for business.

$\mathrm{H}_{1}$ (1): SMEs are not unfamiliar with or inactive in using the internet for business. 


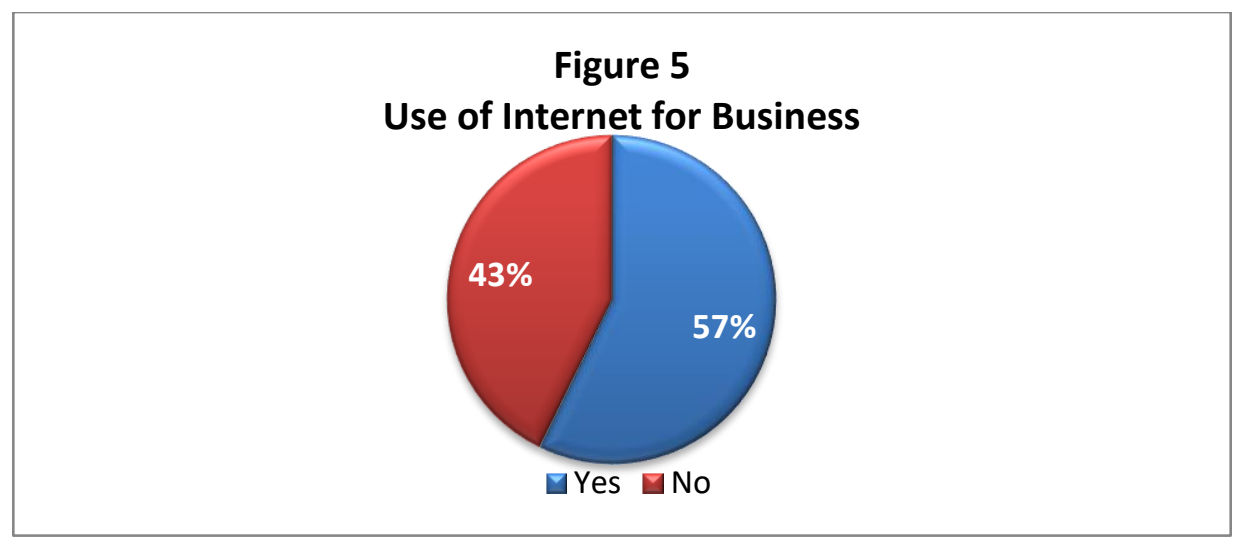

Table 2

\begin{tabular}{|ll|l|l|l|}
\hline & \multicolumn{3}{|l|}{\begin{tabular}{l}
\multicolumn{2}{l|}{ Internet for } \\
Business
\end{tabular}} & Total \\
\hline & & Yes & no & yes \\
\hline $\begin{array}{llll}\text { Internet } \\
\text { Access }\end{array}$ & 71 & 42 & $113(91 \%)$ \\
& & & \\
Total & & 0 & 11 & $11(9 \%)$ \\
\end{tabular}

As the survey results in Figure 5 and Table 2 indicate, 91 percent of the owners have internet access but only 57percent use it for business purpose. This means that in Pakistan SMEs are not fully utilizing the technology of internet and social media to their benefit.

Table 3

\begin{tabular}{|c|c|c|c|c|c|}
\hline & & Value & $\begin{array}{l}\text { Asymp. } \\
\text { Std. } \\
\text { Error(a) }\end{array}$ & $\begin{array}{l}\text { Appro } \\
\text { x. T(b) } \\
\end{array}$ & $\begin{array}{l}\text { Approx. } \\
\text { Sig. }\end{array}$ \\
\hline $\begin{array}{l}\text { Nominal by } \\
\text { Nominal }\end{array}$ & $\begin{array}{l}\text { Contingency } \\
\text { Coefficient }\end{array}$ & & & & .000 \\
\hline Ordinal by Ordinal & $\begin{array}{l}\text { Gamma } \\
\text { Spearman Correlation }\end{array}$ & $\begin{array}{l}1.000 \\
.361\end{array}$ & $\begin{array}{l}.000 \\
.055\end{array}$ & $\begin{array}{l}3.708 \\
4.277\end{array}$ & $\begin{array}{l}.000 \\
.000(\mathrm{c})\end{array}$ \\
\hline $\begin{array}{l}\text { Interval by Interval } \\
\mathrm{N} \text { of Valid Cases }\end{array}$ & Pearson's R & $\begin{array}{l}.361 \\
124\end{array}$ & .055 & 4.277 & $.000(\mathrm{c})$ \\
\hline
\end{tabular}

Table 3 shows that the level of significance is 0.000 - hence, the null hypothesis is accepted meaning that, in Pakistan, SMEs are unfamiliar with and inactive in using internet for business. The reason for the low-level use of the internet is the lack of awareness about its potential, specifically for business use. 


\section{Hypothesis \#2:}

$\mathrm{H}_{0}$ (2): SMEs in Pakistan lack awareness about promoting businesses through the social media.

$\mathrm{H}_{1}$ (2): SMEs in Pakistan do not lack awareness about promoting businesses through the social media.

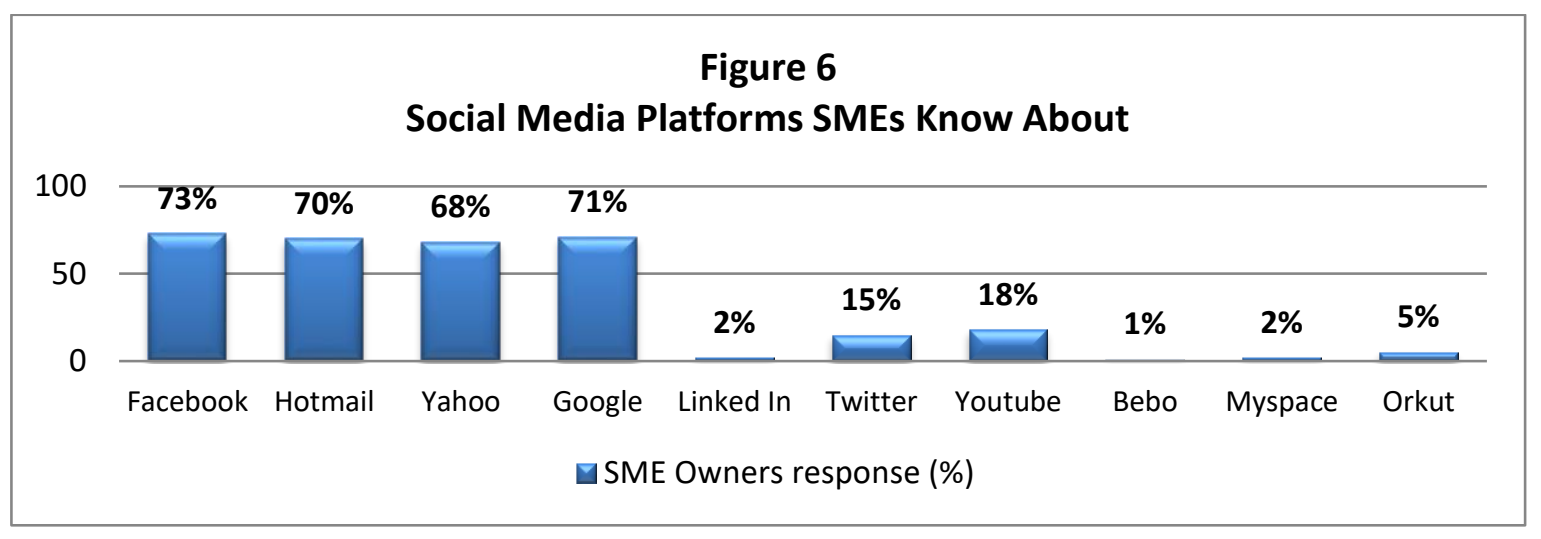

Figure 6 indicates the percentage of SME owners who have heard of particular Social Media sites. Facebook (73 percent) clearly leads the way, with Google (71 percent), Hotmail (70 percent), and Yahoo (68 percent) in close succession. Surprisingly, YouTube (18percent) features very low and is at about the same level as Twitter (15percent). It is encouraging to note that SME owners are aware of the top Social Media sites, but usage is quite limited for promoting businesses. Further probing revealed the following picture with regard to the use of Social Media for business:

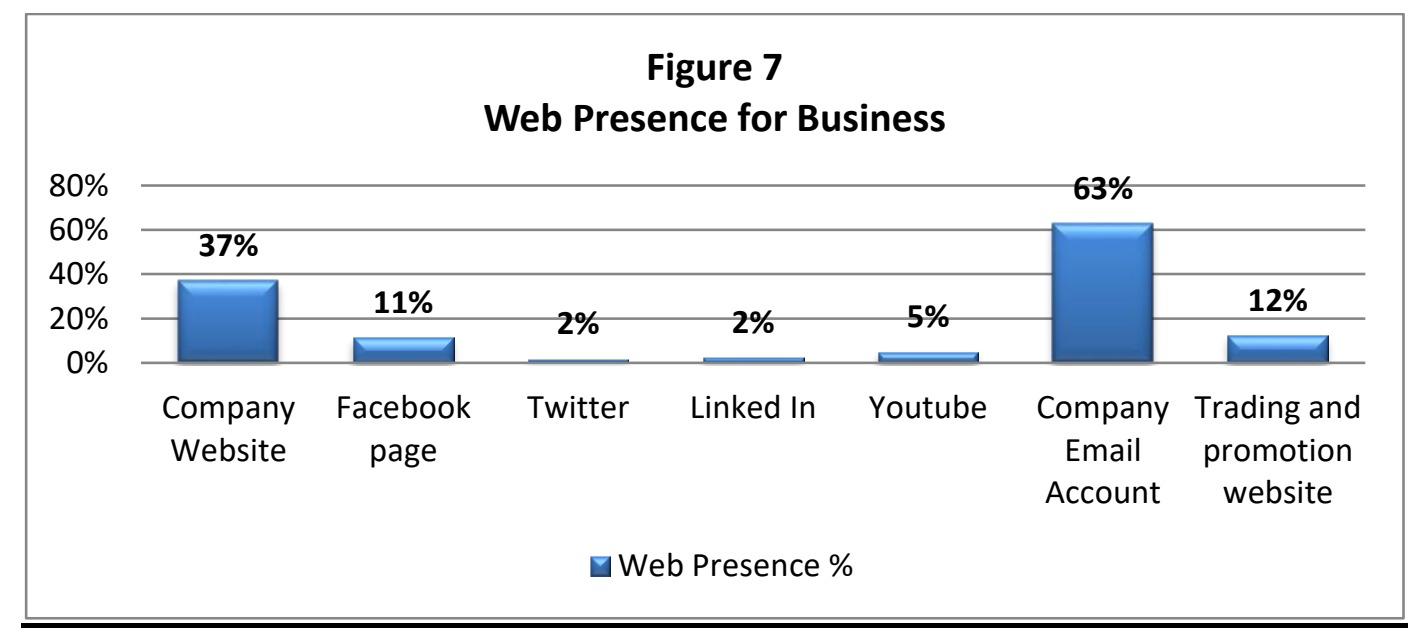

As Figure 7 shows, most SMEs who use Social Media limit it largely to emails (63 percent) or have a Website (37 percent) in place. But very few have a presence on the more popular sites such as Facebook, Twitter, Linked in, YouTube, or Trading and Promotion website. SMEs 
know about these sites but either do not yet realize their importance or do not know how to make use of them to promote their business. Hence, it can be deduced that null hypothesis is accepted suggesting that SMEs in Pakistan lack awareness about promoting businesses through the social media.

\section{Hypothesis \# 3}

$\mathrm{H}_{0}$ (3): There is a positive relationship between opportunities in SMEs business and internet usage for business.

$\mathrm{H}_{1}$ (3): There isn't a positive relationship between opportunities in SMEs business and internet usage for business.

\section{Table 4}

\begin{tabular}{|ll|l|l|l|l|l|l|}
\hline \multicolumn{7}{|l|l|}{} & \multicolumn{3}{l|}{ Immediate Business Opportunities } & Total \\
\hline & $\begin{array}{l}\text { Very } \\
\text { Low }\end{array}$ & Low & $\begin{array}{l}\text { Norm } \\
\text { al }\end{array}$ & High & $\begin{array}{l}\text { Very } \\
\text { High }\end{array}$ & \\
\hline $\begin{array}{l}\text { Internet } \\
\text { for } \\
\text { Business }\end{array}$ & yes & 2 & 8 & 5 & $39(\mathbf{3 2 \%})$ & $\begin{array}{l}17 \\
(\mathbf{1 4 \%})\end{array}$ & $71(\mathbf{5 7 \%})$ \\
Total & 4 & 13 & 5 & 27 & 4 & $\begin{array}{l}53(\mathbf{4 3 \%}) \\
124 \\
(\mathbf{1 0 0 \%})\end{array}$ \\
\hline
\end{tabular}

Table 4 shows that 57 percent respondents use internet for business purposes of whom $46 \%$ have a likelihood of getting immediate (high or very high) business opportunities.

\section{Chi-Square Tests}

\section{Table 5}

\begin{tabular}{|l|l|l|l|}
\hline & Value & df & $\begin{array}{l}\text { Asymp. Sig. } \\
\text { (2-sided) }\end{array}$ \\
\hline Pearson Chi-Square & $9.678(\mathrm{a})$ & 4 & .046 \\
Likelihood Ratio & 10.115 & 4 & .039 \\
Linear-by-Linear & 8.831 & 1 & .003 \\
Association & & & \\
N of Valid Cases & 124 & & \\
\hline
\end{tabular}


Table 6

\begin{tabular}{|ll|l|l|l|l|}
\hline & & Value & $\begin{array}{l}\text { Asymp. } \\
\text { Std. } \\
\text { Error(a) }\end{array}$ & $\begin{array}{l}\text { Appro } \\
\text { x. T(b) }\end{array}$ & $\begin{array}{l}\text { Approx. } \\
\text { Sig. }\end{array}$ \\
\hline $\begin{array}{l}\text { Nominal by } \\
\begin{array}{l}\text { Nominal } \\
\text { Interval by }\end{array}\end{array}$ & $\begin{array}{l}\text { Contingency } \\
\text { Coefficient } \\
\text { Interval } \\
\text { Prdinal by }\end{array}$ & .269 & & & .046 \\
$\begin{array}{l}\text { Ordinal } \\
\text { N of Valid Cases }\end{array}$ & $\begin{array}{l}\text { Spearman } \\
\text { Correlation }\end{array}$ & -.268 & .085 & -3.072 & $.003(\mathrm{c})$ \\
\hline
\end{tabular}

Since the levels of significance indicated in Table 5 and Table 6 are less than 0.10 , the null hypothesis is accepted proving that "There is a positive relationship between opportunities in SMEs business and internet usage for business". This leads us to conclude that opportunities increase for SME businesses in Pakistan when they use internet for business purposes.

\section{Hypothesis \# 4}

$\mathrm{H}_{0}$ (4): Use of social media is only beneficial for a few types of SMEs.

$\mathrm{H}_{1}$ (4): Use of social media is not only beneficial for a few types of SMEs.

Regression Analysis was performed to identify the relationship between the type of business that and Social Media can play a part in "materializing sales".

Table 7

\begin{tabular}{|c|c|c|c|c|c|}
\hline $\begin{array}{l}\text { Mode } \\
1\end{array}$ & $\mathrm{R}$ & R Square & $\begin{array}{l}\text { Adjusted } \\
\text { R Square }\end{array}$ & $\begin{array}{l}\text { Std. Error } \\
\text { of the } \\
\text { Estimate }\end{array}$ & $\begin{array}{l}\text { Durbin- } \\
\text { Watson }\end{array}$ \\
\hline 1 & $.099(\mathrm{a})$ & .010 & .002 & 1.08089 & 1.831 \\
\hline
\end{tabular}

In table 7, since the Durbin Watson value is close to 2, it is concluded that a direct relationship does not exist between the use of Social Media and impact on sales of any specific type of business. This means that "Use of social media is not only beneficial for a few types of SMEs". Hence Hypothesis \# 4 is accepted. 


\section{Hypothesis \# 5}

$\mathrm{H}_{0}$ (5): SMEs use internet mainly to enhance company image.

$\mathrm{H}_{1}$ (5): SMEs do not use internet mainly to enhance company image.

Among those SME businesses that use the internet for business purposes the top six factors highlighted by the survey, in order of priority, are:

\begin{tabular}{|l|l|}
\hline Rank & Internet usage driver \\
\hline 1 & Low-cost communication \\
\hline 2 & Access to external emails \\
\hline 3 & Easy access to potential customers \\
\hline 4 & Search mechanism for Web addresses \\
\hline 5 & Forming and extending business network \\
\hline 6 & Advertising/promoting business \\
\hline
\end{tabular}

The least important areas where Internet was used by business were (\#1 being the least important):

\begin{tabular}{|l|l|}
\hline Rank & Internet usage driver \\
\hline 1 & Product delivery \\
\hline 2 & Linking to a professional body \\
\hline 3 & $\begin{array}{l}\text { Access to government and trade } \\
\text { organization data }\end{array}$ \\
\hline 4 & Inter-office documents exchange \\
\hline 5 & Online sales and transactions \\
\hline
\end{tabular}

The survey results rejected the null hypothesis stating that "SME use internet mainly to enhance company image". Hence, according to the study, the top-two factors which drive SMEs to use internet in Pakistan are low-cost communication and access to external emails.

\section{Hypothesis \# 6}

$\mathrm{H}_{0}(6)$ : SMEs prefer SMS marketing over internet or social media marketing.

$\mathrm{H}_{1}$ (6): SMEs do not prefer SMS marketing over internet or social media marketing. 


\section{Table 8}

\section{Paired Samples Statistics}

\begin{tabular}{|ll|l|l|l|l|}
\hline & & & $\begin{array}{l}\text { Std. } \\
\text { Deviation }\end{array}$ & $\begin{array}{l}\text { Std. } \\
\text { Error } \\
\text { Mean }\end{array}$ \\
\hline $\begin{array}{l}\text { Pair } \\
1\end{array}$ & SMS Marketing & 1.3226 & 124 & .46936 & .04215 \\
& $\begin{array}{l}\text { Internet for } \\
\text { Business }\end{array}$ & 1.4274 & 124 & .49671 & .04461 \\
\hline
\end{tabular}

\section{Table 9}

\section{Paired Samples Correlations}

\begin{tabular}{|ll|l|l|l|}
\hline & & $\mathrm{N}$ & $\begin{array}{l}\text { Correlatio } \\
\mathrm{n}\end{array}$ & Sig. \\
\hline $\begin{array}{l}\text { Pair } \\
1\end{array}$ & $\begin{array}{l}\text { SMS Marketing \& } \\
\text { Internet for } \\
\text { Business }\end{array}$ & 124 & -.073 & .420 \\
\hline
\end{tabular}

Tables 8 and 9 indicate that SMS marketing is preferred by SMEs in Pakistan in comparison to Internet-social media marketing. Hence the null hypothesis stand i.e. SMEs prefer SMS marketing over internet or social media marketing. However, there is also a negative correlation between the two variables which means it is not necessary that SMEs performing SMS marketing should also be performing internet social media marketing and vice versa.

\section{CONCLUSION}

The consolidated results of the research show that though usage of Internet and Social Media sites is increasing in Pakistan at a noticeable pace, but SMEs are not effectively utilizing this opportunity to market their products or create awareness of their company or brands. A key incentive for using Social Media is that it is much cheaper than any of the traditional media vehicles, but it does require a level of expertise to be effective. That expertise can either be created in a company or in the case of SMEs obtained through specialist service providers whose number is growing rapidly.

As the survey shows, SMEs in the service industry use internet for business more than those in manufacturing and trading. Social Media can benefit any sector, the cost involved is low and the absence of expertise can be overcome by outsourcing the work. Hence, sectors where the usage is either low or nonexistent are missing out on a major opportunity. 
In Pakistan businesses mainly restrict the use of social media to low-cost communication. When we look at other countries in the region such as India, we realize that SMEs there understand the importance of this medium and do not shy away from it. Interestingly SMEs in Pakistan are aware of many top-rated social media sites but when it comes to using it for business purpose, they are largely inactive.

Our research also proves that the SMEs in Pakistan using internet-social media for business are successful in gaining business advantage in terms of materializing their sales and finding good opportunities for growth.

\section{RECOMMENDATIONS}

For SMEs, Social Media as a concept is strongly recommended. The choice of sites likes Facebook, Youtube, Twitter, LinkedIn etc is related to company objectives and their target audience. Existing SMEs should consider using Social Media because as per our research it will benefit them immensely from a business perspective. 


\section{REFERENCES}

Agrawal, A., \& Saxena, K. (2019). Social Media Marketing for Growth of SMEs.

Alexander, C., J.M. Pearson, L. Crosby. 2003. "The Transition to E-Commerce: A Case Study of a Rural-Based Travel Agency." Journal of Internet Commerce 2(1): 49-63.

Ali Iqbal, Future of E-Commerce in Pakistan. http://ezinearticles.com/?Future-of-ECommerce-in-Pakistan\&id=1974082

Barker, N. (1994) The Internet as a Reach Generator for Small Business. Unpublished Masters Thesis, Business School, University of Durham.

Benjamin, R., and Wigand, R. (1995) "Electronic Markets and Virtual Value Chains on the Information Superhighway." Sloan Management Review, 62-72, (Winter).

Bradshaw, C., Dodds, K., Crumbley, J., Sutherland, M., \& Shaw, A. (2019). Social Media in the SME Business to Business Environment and Toolkit.

Chau, S. 2003. "The Use of E-Commerce Amongst Thirty-Four Australian SMEs: An Experiment or a Strategic Business Tool? Journal of Systems and Information Technology 7(1): 49-66.

Cheng, C. C., \& Shiu, E. C. (2019). How to enhance SMEs customer involvement using social media: The role of Social CRM. International Small Business Journal, 37(1), 22-42.

Chong, S., Hoekstra, R., Lemmers, O., Van Beveren, I., Van Den Berg, M., Van Der Wal, R., \& Verbiest, P. (2019). The role of small-and medium-sized enterprises in the Dutch economy: an analysis using an extended supply and use table. Journal of Economic Structures, 8(1), 1-24.

Constantinides, E., \& Fountain, S. J. (2008). Web 2.0: Conceptual foundations and marketing issues. Journal of direct, data and digital marketing practice, 9(3), 231-244.

Cordeiro, W.P. 2003. "A Case Study: How a Retail Jewelry Store Learned to Compete in the E-Commerce Market Place." Journal of Internet Commerce 2(1): 19-28.

Cronin, B., Overfelt, K., Fouchereaux, K., Manzvanzvike, T., Cha, M., and Sona, E. (1994) "The Internet and Competitive Intelligence: A Survey of Current Practice." International Journal of Information Management, 14: 204-222.

Daniel, E. and Wilson, H., 2002. Adoption Intentions and Benefits Realised: A Study of ECommerce in UK SMEs. Journal of Small Business and Enterprise Development, 9(4), pp.331-348. 
David Dean, Sebastian Digrande, Dominic Field, Andreas Lundmark, James O Day, John Pineda, Paul Zwillenberg (2012) “The \$4.2 Trillion opportunity” The internet economy in the G-20, The Boston Consulting Group March 2012.

Delerue, H., Kaplan, A. M., \& Haenlein, M. (2012). Social media: back to the roots and back to the future. Journal of Systems and Information Technology.

Fuller, T., and Jenkins, A. (1995) "Public Intervention in Entrepreneurial Innovation and Opportunism: Short Cuts or Detours to the Information Superhighway?" Babson Entrepreneurship Conference, London Business School.

Gherghina, Ș. C., Botezatu, M. A., Hosszu, A., \& Simionescu, L. N. (2020). Small and Medium-Sized Enterprises (SMEs): The Engine of Economic Growth through Investments and Innovation. Sustainability, 12(1), 347.

Global Technology Forum: Pakistan Internet: $1.5 \mathrm{~m}$ broadband users likely by 2010 ; from Dialog NewsEdge.[Online].Available at: http://www.ebusinessforum.com/index.asp?layout=printer_freindly\&doc_id=8991

H. Mushtaq, Imran Sadiq, Syed Noman Ali (2012) "Internet Markets \& e-Advertising Active Models in Pakistan" Proceedings of 2nd International Conference on Business Management (ISBN: 978-969-9368-06-6).

Hammad, Haroon 2009 "Prospects of adopting on-Line advertising: Firms practicing eBusinesses in Pakistan" ICOBM Vol 2.

Henderson, J.R. 2001. "Networking with E-Commerce in Rural America." The Main Street Economist, September, pp 1-4, Federal Reserve Bank of Kansas City, http://www.kc.frb.org/RegionalAffairs/Mainstreet/MSE_0901.pdf

Hoffman, D. L., and Novak, T. P. (1996) "A New Marketing Paradigm for Electronic Commerce." http://www2000.ogsm.vanderbilt.edu/novak/new.marketing.paradigm.html

Kharub, M., \& Sharma, R. (2020). An integrated structural model of QMPs, QMS and firm's performance for competitive positioning in MSMEs. Total Quality Management \& Business Excellence, 31(3-4), 312-341.

Lymer, A., Johnson, R. and Nayak, A. (1996) "The Internet and the Small Business: Case Studies in Business Development and Technology" in the Proceedings of the 19th ISBA National Small Firms and Research Conference. Birmingham, UK.

Mandelli, A. (2005) 'Banners, e-mail, advertainment and sponsored search: proposing a value perspective for online advertising'Int. J. Internet Marketing and Advertising, Vol. 2, Nos. 1/2, pp.92-108. 
Poon, S. and Swatman, P.M.C. 1997. "Small Business Use of the Internet: Findings From Australian Case Studies." International Marketing Review 14 (5): 385-402.

Poon, S., and Swatman, P. M. C. (1995) "The Internet for Small Businesses: An Enabling Infrastructure for Competitiveness." Proceedings of the Fifth Internet Society Conference, (ed.) Chon K., Hawaii, 221-231.

Poon, S., and Swatman, P. M. C. (1996) "Electronic Networking Among Small Business in Australia--An Exploratory Study" in the Proceedings of the Ninth International Conference on EDI-IOS (eds.) Swatman, P. M. C., et al., Slovenia, 446-460.

Poon, S., and Swatman, P. M. C. (1997) "In-Depth Understanding on Issues Facing Small Business Internet Use: A Case Study Approach." Working Paper Series, Swinburne University of Technology, Australia.

Quelch, J. A., and Klein, L. R. (1996) "The Internet and International Marketing." Sloan Management Review, 60-75 (Spring).

Sieber, P. (1996a) "Swiss Firms on the Internet: An Empirical Study" in the Proceedings of the Fourth European Conference on Information Systems (eds.) Coelho, J. D., et al., Portugal, 183-199.

Sieber, P. (1996b) "Virtuality as Strategic Approach for Small and Medium Sized IT Companies to Stay Competitive in a Global Market" in the Proceedings of the International Conference on Information Sytems, Cleveland, Ohio.

The Economist Intelligence Unit; Overview of e-commerce in Pakistan. [Online]. Available at http://www.ebusinessforum.com/index.asp?layout=newdebi\&country_id=PK\&country $=$ Pakistan $\&$ channelid $=6 \&$ title $=$ Doing + e-business + in + Pakistan

Tripathi, A. (2019). SMEs In Saudi Arabia-An Innovative Tool for Country's Economic Growth. Sci. Int.(Lahore), 31(2), 261-267.

Zwass, V., 1996. Electronic Commerce: Structures and Issues. International Journal of Electronic Commerce, 1(1), pp.1-23. 